\title{
Investigation of Butane-butylene Technical Mixtures Transformation Over Modified Microporous Materials Prepared by Ion Exchange Method Into Liquid Fraction Rich in Aromatic Hydrocarbons
}

\author{
IULIEAN VASILE ASAFTEI ${ }^{1}$, NECULAI CATALIN LUNGU ${ }^{1}$, MARIA IGNAT ${ }^{1 *}$, ION SANDU2* \\ ${ }^{1}$ Alexandru loan Cuza University of lasi, Faculty of Chemistry, 11 Carol I Blvd, 700506, Iasi, Romania \\ ${ }^{2}$ ARHEOINVEST Interdisciplinary Platform, Al. I. Cuza University of lasi, 22 Carol I Blvd, 700506,Iasi, Romania
}

\begin{abstract}
The $\mathrm{Zn}$ and Ni were introduced into HZSM-5 zeolite by ion exchange method with aqueous solutions of $\mathrm{Zn}\left(\mathrm{NO}_{3}\right)$ and $\mathrm{Ni}\left(\mathrm{NO}_{3}\right)_{2}$, to investigate the catalytic activity and selectivity of modified $\mathrm{Zn}-\mathrm{HZSM}-5$ and NiHZSM-5 catalysts for conversion of butane-butylenes technical mixtures in a fixed-bed stainless-steel reactor (Twin Reactor System Naky) at 450C , at atmospheric pressure for Zn-HZSM-5 and at 4 atm. total pressure for Ni-HZSM-5 and at a space velocity (WHSV) of $1 h^{-1}$. The catalysts were characterized using XRD, SEM, and $\mathrm{NH}_{3}-\mathrm{TPD}$ analysis for their structure, morphology and acidity. The catalytic activity of the same catalyst were examined during over 10 catalytic tests (with regeneration of catalyst after each test) using mixtures of butanes-butylenes.
\end{abstract}

Keywords: conversion, light hydrocarbons, Zn- HZSM-5, Ni-HZM-5, BTX

Light alkanes and alkenes aromatization over zeolite based catalysts is well known. It has been shown that HZSM-5 zeolite can be modified by incorporation of metals and metal oxides in order to obtain catalysts for selective hydrocarbons conversion [1-6].

Activity, selectivity and stability of the zeolite catalysts for those shape selective reactions (e.g. aromatization of lighthydrocarbons) depend not only on the porous structure of the zeolite but also on the density of the acid sites and their strength distribution, as well as on metal sites distribution and metal support interaction [7]. The catalyst systems prepared in this way operate as bifunctional catalysts. The addition of a catalytic (de)hydrogenating function e.g. $\mathrm{Ga}, \mathrm{Zn}, \mathrm{Ni}, \mathrm{Pt}, \mathrm{Ag}$, etc., to HZSM-5 is known to significantly enhance the activity and selectivity to aromatic hydrocarbons BTX (benzene, toluene, xylenes) for the aromatization of light hydrocarbons [ 7-82]. Among these additives, Ga has been most extensively studied because of its superior selectivity to aromatics and the high stability of Ga-HZSM-5.

The catalytic performance of Zn-HZSM- 5 is comparable to that of Ga-HZSM-5, but Zn is less stable due the high vapor pressure of $Z n^{2+}[4]$. The problem of $Z n$ volatilization can however be alleviated by alloying $\mathrm{Zn}$ with $\mathrm{Cu}, \mathrm{Ni}, \mathrm{Ga}$ or $\mathrm{Pd}[37,52,59,83,84]$.

$\mathrm{Ni}-\mathrm{HZSM}-5$ (or Ag-HZSM-5) catalysts exhibit a good activity and selectivity towards BTX aromatics in conversion of light alkanes and alkenes [74- 81].

In the present paper, we present the (comparative) results obtained in the conversion of butane-butylenes technical mixtures (in FCC gasses) in a fixed-bed stainlesssteel reactor over Zn-HZSM-5 and Ni-HZSM- 5 catalysts prepared by ion exchange method with aqueous solutions of $\mathrm{Zn}\left(\mathrm{NO}_{3}\right)_{2}$ and $\mathrm{Ni}\left(\mathrm{NO}_{3}\right)_{2}$.

\section{Experimental part}

Synthesis

The parent Na-ZSM-5 was synthesized with ethylene glycol as the template organic molecule. The starting materials were: sodium silicate solution $\left(29.63 \% \mathrm{SiO}_{2}\right.$ $9.55 \% \mathrm{Na}_{2} \mathrm{O}$ and $\left.60.8 \% \mathrm{H}_{2} \mathrm{O}\right)$, aluminum sulphate $\mathrm{Al}_{2}\left(\mathrm{SO}_{4}\right)_{3}^{\prime}$ '"18 $\mathrm{H}_{2} \mathrm{O}$, concentrated sulphuric acid, and distilled water [86].

Crystallization of the homogeneous gel took place over $24 \mathrm{~h}$ at autogenously pressure and $180 \pm 5^{\circ} \mathrm{C}$ in steel stainless autoclaves with intermittent stirring. The synthesis product were filtered, washed repeatedly with distilled water, dried at $110^{\circ} \mathrm{C}$ in air for $6 \mathrm{~h}$ and calcined at $550^{\circ} \mathrm{C}$ in air for $6 \mathrm{~h}$ in order to remove the organic agent.

The calcined Na-ZSM-5 was converted into $\mathrm{H}$-form by three successive ion exchanges with $1 \mathrm{M} N \mathrm{NH}_{1} \mathrm{NO}_{3}$ solution at $80^{\circ} \mathrm{C}$ for $6 \mathrm{~h}$ (solid : liquid ratio $=1 \div 5$ ). Then, the zeolite is separated from the solution by filtering and washing with distillate water. After that, the catalyst is dried over night at $110^{\circ} \mathrm{C}$ and calcined in air at $550^{\circ} \mathrm{C}$ for $6 \mathrm{~h}$. HZSM-5 sample was converted by ion exchange with $0.1 \mathrm{M}$ aqueous solutions of $\mathrm{ZnNO}$ in $\mathrm{Zn}-\mathrm{HZSM}-5$ with content of metal at $1.39 \%$ wt. and was converted to Ni-HZSM- 5 by process of ion exchanges with $0.1 \mathrm{M} \mathrm{Ni}\left(\mathrm{NO}_{3}\right.$ ), aqueous solution under stirring at $80^{\circ} \mathrm{C}$. The $\mathrm{Ni}-\mathrm{HZSM}^{3}-5$ sample was filtered, washed, dried at $110^{\circ} \mathrm{C}$ for $6 \mathrm{~h}$ and calcined at $450^{\circ} \mathrm{C}$ in air for $6 \mathrm{~h}$. The Ni contained in the sample was $1.34 \%$. The $\mathrm{Zn}$ HZSM-5 and Ni-HZSM-5 powders with $20 \%$ wt., $\gamma-\mathrm{Al}_{2} \mathrm{O}_{3}$ as binder was extruded and then cutinto short cylinders, dried at $110^{\circ} \mathrm{C}$ for $6 \mathrm{~h}$ and calcined at $550^{\circ} \mathrm{C}$ in air for $6 \mathrm{~h}$.

\section{Catalyst characterization}

The structure type, phase purity and degree of crystallinity were determined by X-ray powder diffraction pattern which were obtained on a Philips PW 1830 diffractometer using Ni filtered $\mathrm{Cu} \mathrm{K}$ radiation at a scanning speed of $0.02^{\circ} \mathrm{s}^{-1}$ in the range of $6-45,2 \theta$. XRD powder pattern of the Na-ZSM-5 sample exhibit only diffraction lines proper to MFI structure high crystallinity. The pattern confirmed that the synthesized zeolite has the structure identical to MFI-type zeolite [86]. The morphology and size of the individual crystals were obtained by scanning electron microscopy (SEM) with a Microspec WDX-2A using a $25 \mathrm{kV}$ accelerating potential. The SEM image of 
parent NaZSM-5 revealed the well-defined morphology of crystals indicating highly crystalline material $[37,44,49,51,53,58,61,64]$. Catalytic tests in a fixed-bed continuous flow stainless - steel reactor (a commercial Twin Reactor System Naky Metrimpex, Hungary) was studied. The reaction products (only aromatic BTX) were on-line analyzed by a gas chromatograph Carlo Erba VEGA equipped with a 25 m capillary column filled with SE-52 and flame ionization detection (FID).

The acidity and strength distribution on HZSM-5, ZnHZSM-5 and Ni-HZSM-5 catalysts were measured using Temperature Programmed Desorption (TPD) technique using ammonia. A known weight of the sample was activated in a dry $\mathrm{N}_{2}$ at $500^{\circ} \mathrm{C}$ for $4 \mathrm{~h}$ then cooled to $80^{\circ} \mathrm{C}$ when ammonia was admitted. The amount of ammonia desorbed from 100 to $800^{\circ} \mathrm{C}$ (at a heating rate of $10^{\circ} \mathrm{C}$ / min) was quantitatively monitored by absorption in $1 \mathrm{M} \mathrm{HCl}$. The desorbed ammonia represents the total acidity (weak and strong) of the sample. The TPD ammonia desorption presents two peaks, one at low temperature (LT) and one at high temperature (HT) (table 1). The peak corresponds to higher acid strength and is done to ammonia bound to strong structural Brönsted sites ( $\mathrm{Si}-\mathrm{O}$-Al bridging $\mathrm{OH}$ ), and possible to strong Lewis sites ( $\equiv \mathrm{Al}$ and $\equiv \mathrm{Si}^{+}$). Low temperature peak correspond to less acidic sites (terminal $\mathrm{OH}$ groups, cationic sites $\left.\mathrm{M}^{\mathrm{n}+}, \mathrm{AlO}^{+}\right)$. The temperature and the amount of desorbed ammonia give information about strength and number of the acid sites. The observed enhancement of middle and lover acid sites in the NiHZSM-5 and Zn-HZSM- 5 catalysts is probably the results of the Lewis acid sites created by nickel, and zinc, respectively. It also found that the intensity of strong acid sites (Bronsted probably) decreased compare to parent HZSM-5 [60].

The BET specific surface area was estimated applying the BET equation on sorption isotherms obtained using a Carlo -Erba Sorptomatic Series 1800 instrument at -469K and at sub-atmospheric pressure with nitrogen as the analysis gas. The values of the BET specific surface area and acidity of the Ni-HZSM- 5 and Zn-HZSM- 5 catalysts are presented in table 1.

Temperature programmed desorption spectra of $\mathrm{NH}_{3}$ revealed that the acid strength of HZSM- 5 was considerably reduced by introducing $\mathrm{Zn}^{2+}$ and $\mathrm{Ni}^{2+}$ cations. It was indicated from the results that the acid sites distribution of the Zn-HZSM-5 or Ni-HZSM-5 changed after the metal incorporation in HZSM-5 (the incorporation of the $\mathrm{Zn}^{2+}$ and $\mathrm{Ni}^{2+}$ ions into cationic positions), the medium and strong acid sites, in the catalysts weakened due the effect of $\mathrm{Zn}$ and $\mathrm{Ni}$.

It was found that the intensity of the strong acid sites (Brönsted probably) in the modified zeolite samples decreased compare to HZSM-5.

\section{Catalytic performance}

The catalytic activity of Zn-HZSM-5 and Ni-HZSM-5 for $\mathrm{C}_{-}-\mathrm{C}_{-}=$technical fraction conversion to aromatics $\mathrm{BTX}$, at $40^{\circ} \mathrm{C}$ and atmospheric pressure (Zn-HZSM-5), and at 4atm. (over Ni-HZSM-5) with WHSV $1 \mathrm{~h}^{-1}$, in a fixed-bed continuous flow stainless -steel reactor (a commercial Twin Reactor System Naky Metrimpex, Hungary) was studied. The catalysts were pre-treated with $\mathrm{N}_{2}$ for $6 \mathrm{~h}$ at $450^{\circ} \mathrm{C}$ to remove the adsorbed impurities and the moisture.

The reaction products were separated into liquid and gas fractions through an ice-trap. Composition of products was obtained with two gas chromatographs (GC Carlo Erba, model $C$ and Vega) using a fused silica capillary column ( $25 \mathrm{~m}$ length and $0.32 \mathrm{~mm}$ i.d.) with SE-52 stationary phase and flame ionization detector (FID) for liquid phase and a column ( $6 \mathrm{~m}$ length) with squalane and dimethylsulpholane and a thermal conductivity detector (TCD) for gaseous phase, respectively.

\section{Results and discussions}

Catalytic reactions of technical fraction $\mathrm{C}_{4} / C_{4}=$ on $\mathrm{Zn}$ HZSM-5 catalyst

Before the catalytic tests, the catalyst was heated in reactor at $450^{\circ} \mathrm{C}$ in nitrogen flow for $6 \mathrm{~h}$. The Zn-HZSM-5 was evaluated in ten consecutive tests with intermediary regeneration at $475^{\circ} \mathrm{C}$ for $6 \mathrm{~h}$ in nitrogen with $2 \%$ oxygen flow.

The operating conditions (temperature $450^{\circ} \mathrm{C}$, WHSV $\mathrm{lh}^{-1}$ and atmospheric pressure) were in advance selected to obtain the high yield of liquid product during the catalytic test. The changes of the liquid yield, butenes total conversion and aromatics hydrocarbon BTX concentration over Zn-HZSM-5 catalyst with time on-stream (from four to four hours), are presented in figure 1 .

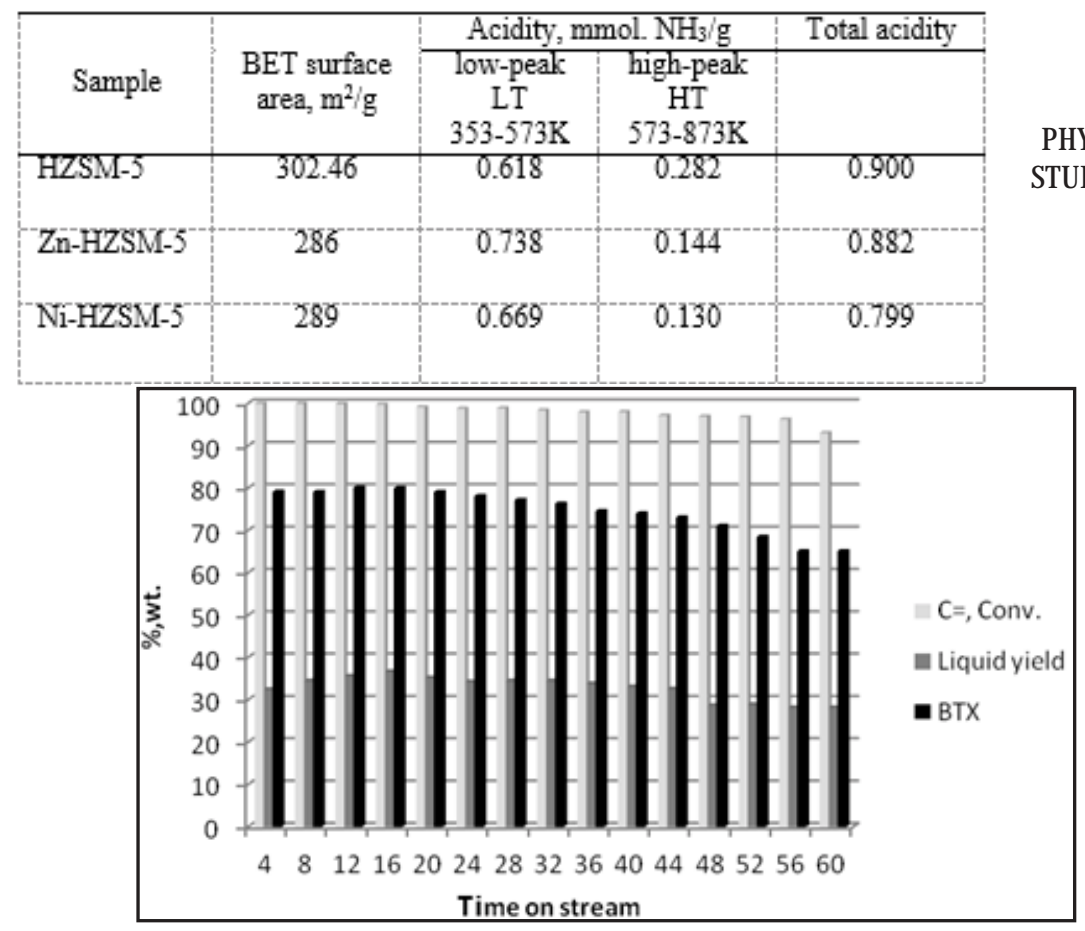

Table 1

PHYSICO-CHEMICAL CHARACTERISTICS OF THE STUDIED CATALYSTS: Ni-HZSM-5 and Zn-HZSM-5 IN COMPARISON WITH HZSM-5
Fig.1. Variation of BTX concentration, butenes conversion, and liquid yield vs. time on stream over Zn-HZSM-5 catalyst at $450^{\circ} \mathrm{C}$, atmospheric pressure and WHSV $1^{-1}$ (Test No.5) 
Butenes are consumed almost in totality during first 44 $\mathrm{h}$ on stream. Butanes are consumed during first $20 \mathrm{~h}$ of reaction after their become mainly components in reaction gases. $\mathrm{C}_{3}$ and $\mathrm{C}_{2}$ hydrocarbons were obtained in more quantity in first $24 \mathrm{~h}$ of reaction. The liquid product yield went up to $32 \%$ and the aromatic hydrocarbons BTX represent over $75 \%$ wt. after $40 \mathrm{~h}$, and finally, $65 \%$ wt. after $60 \mathrm{~h}$ of the time spent test.

Zn presence modifies the acid properties of the HZSM-5 catalyst decreasing the strong acid sites (Bronsted) number and creates new acid sites associated to Zn (Lewis). This element exhibits a strong attraction to hydrogen, preventing thus the hydrogenation of alkenes, and consequently, enhancing aromatization process. Zn presence promotes actualy the formation of aromatics via dehydrogenation of oligomerized and cyclized alkenes (naphtenes).

Due to the dehydrogenating activity of zinc, the hydrogen appears in the gaseous fraction (up to $42 \%$ vol., after $24 \mathrm{~h}$ ) and the aromatic hydrocarbons become mainly components of the liquid fraction results in the reaction mixture (fig. 2).

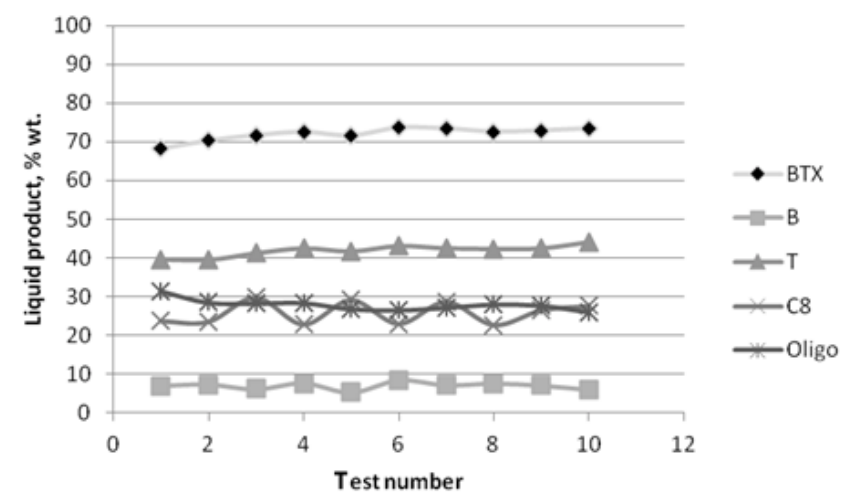

Fig.2.The aromatics and $\mathrm{C}_{5}+$ fraction (Oligo) average output over $\mathrm{Zn}$-HZSM-5 catalyst $\left(450^{\circ} \mathrm{C}\right.$, atmospheric pressure and WHSV $\left.=1 \mathrm{~h}^{-1}\right)$;

(C8 - Xylenes + ethyl benzene, T - toluene, B - benzene, BTX benzene, toluene, xylenes)

The yield of BTX hydrocarbons follows the series:

Toluene > Aromatics hydrocarbons $\mathrm{C}_{8}>>$ benzene

In the liquid product the aromatic hydrocarbons, BTX, are predominant over $71 \% \mathrm{wt}$ in all ten catalytic tests performed over Zn-HZSM-5 catalyst, toluene being the main aromatic hydrocarbon.

Zn cations distributed in HZSM-5 zeolite structure were involved in all dehydrogenation steps required for the alkane's aromatization, but only by catalyzing the recombinative desorption of $\mathrm{H}$-atoms as $\mathrm{H}_{2}$, while all other steps occurred on acid sites.

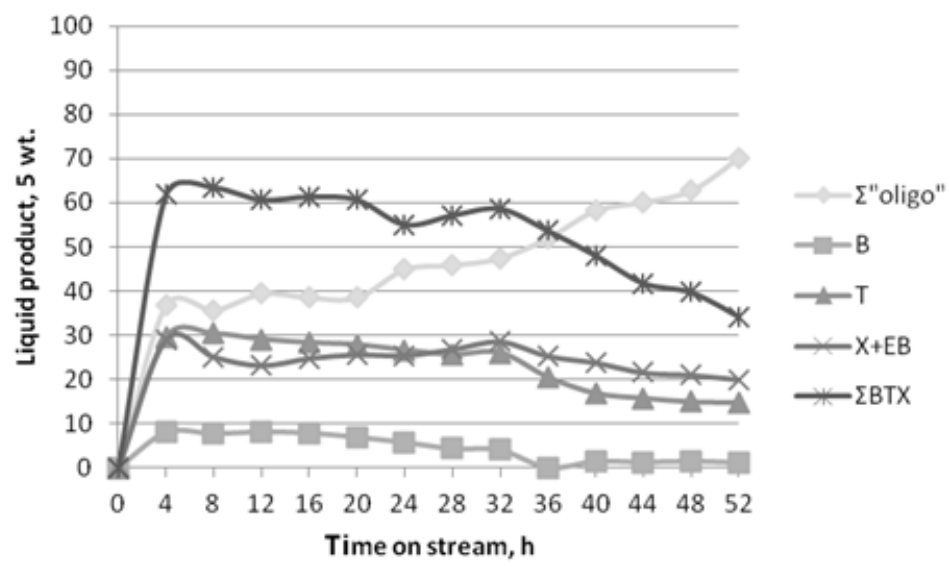

Fig.4.The aromatics hydrocarbons, BTX and $\mathrm{C}_{5}+$ fraction (Oligo) average output over Ni-HZSM-5 catalyst $\left(450^{\circ} \mathrm{C}, 4 \mathrm{~atm}\right.$. pressure and WHSV $\left.=1 \mathrm{~h}^{-1}\right)$ 


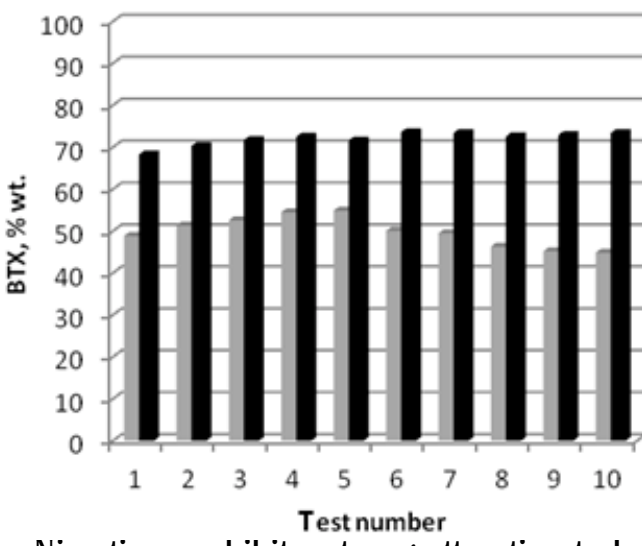

Ni cations exhibit a strong attraction to hydrogen, thus preventing the hydrogenation of alkenes, and consequently, enhancing the aromatization process (only in the first hours of the reaction). Nickel presence promotes actually the formation of aromatics via dehydrogenation of oligomerized and cyclized alkenes (naphtenes).

Due to the dehydrogenating activity of $\mathrm{Ni}$, the hydrogen appears in the gaseous fraction and the aromatic hydrocarbons are the main components of liquid fraction results in reaction (but in small quantities compare to $\mathrm{Zn}$ HZSM-5) (fig. 4).

Toluene $\approx$ Aromatics hydrocarbons $\mathrm{C}_{8}$ (xylenes + ethyl benzene) $>>$ benzene.

Aromatic hydrocarbons were mainly toluene (of $\sim 24.0$ wt $\%$ ) and xylenes (of $\sim 22.0 \mathrm{wt} \%$ ), benzene being about $3.5 \mathrm{wt} \%$ (middle value per tests). BTX aromatic hydrocarbons are the major components only in the first $30 \mathrm{~h}$ of the reaction, when the concentration in liquid fraction decreases below 50\%. wt. The aliphatic hydrocarbons $\mathrm{C}_{5}-\mathrm{C}_{10}$ (n-+i-alkanes) and aliphatic hydrocarbons with more than 10 carbon atoms $\left(>C_{10}\right.$ ) (denoted as $\Sigma$ oligo) are the main components in the liquild fraction after about 24-30 $\mathrm{h}$ of reaction in all ten catalytic tests performed on Ni-HZSM-5, as the figure 4 reveals.

A comparison of the aromatic hydrocarbons BTX concentration in the liquid fraction resulted on Zn-HZSM-5 and Ni-HZSM-5 (middle values for the test) in ten catalytic
Fig.5. Variation of BTX aromatic hydrocarbons concentration, middle values per tests, in the liquid products resulted during the conversion of butanes /butenes technical fraction over Zn-HZSM-5 and Ni-HZSM-5 catalysts. tests of aromatization of butanes-butylenes $\mathrm{C}_{4} / \mathrm{C}_{4}=$ technical fraction is presented in the figure 5 .

On Zn-HZSM-5 (nitrate) the average BTX concentration is over $72 \%$ wt. in liquid products and on Zn-HZSM-5 (acetate) not exceed of $55 \% \mathrm{wt}$ (middle values per tests).

Zn-HZSM-5 and Ni-HZSM-5 catalyze alkane's dehydrogenation and aromatization reactions. Alkanes undergo two primary reactions: dehydrogenation to alkenes and $\mathrm{H}_{\text {, }}$ and cracking to light alkanes and alkenes. Alkenes then form aromatic hydrocarbons via oligomerization, cracking and isomerization reactions and alkenes hydrogenate to form the light alkanes $\mathrm{C}_{2}-\mathrm{C}_{4}$ respectively, via both hydrogen transfer from co-adsorbed intermediates and dissociative adsorption of $\mathrm{H}_{2}$. The reaction pathways resemble those occurring on $\mathrm{HZSM}-5$, but $\mathrm{Ni}^{2+}$ and $\mathrm{Zn}^{2+}$ cations provide alternative pathways for the removal of hydrogen atoms in adsorbed intermediates as $\mathrm{H}_{2} . \mathrm{Zn}^{2+}$ and $\mathrm{Ni}^{2+}$ cations increase the reversibility of hydrogen adsorption-desorption steps. As in the case of gallium exchanged HZSM-5 zeolites these reactions appear to proceed via bifunctional pathways involving acid $-\mathrm{OH}$ groups and exchanged metal cations $[25,26,43,53,54,60$, 82].

$\mathrm{Ni}-\mathrm{HZSM}-5$ shows higher yields for aromatic hydrocarbons and $\mathrm{H}_{2}$ than $\mathrm{HZSM}-5$ because $\mathrm{Ni}^{2+}$ cations catalyze the recombinative desorption of hydrogen atoms as $\mathrm{H}_{2}$, as shows previouslyalso for $\mathrm{Zn}^{2+}$ cations. This desorption step is not quasiecquilibrated during alkanes reactions on any

\begin{tabular}{|c|c|c|c|c|c|c|c|c|c|c|}
\hline \multicolumn{11}{|c|}{ Zn-HZSM-5 (nitrate) } \\
\hline & $\mathrm{T1}$ & $T 2$ & T3 & T4 & T5 & T6 & T7 & T8 & T9 & T10 \\
\hline $\begin{array}{l}\text { Temp. } \\
{ }^{\circ} \mathrm{C}\end{array}$ & 450 & 450 & 450 & 450 & 450 & 450 & 450 & 450 & 450 & $450^{-}$ \\
\hline $\begin{array}{l}\text { Press., } \\
\text { atm. }\end{array}$ & 1 & 1 & 1 & 1 & 1 & 1 & 1 & 1 & 1 & 1 \\
\hline $\begin{array}{l}\text { WHSV, } \\
\mathrm{h}^{-1}\end{array}$ & 1 & 1 & 1 & 1 & 1 & 1 & 1 & 1 & 1 & 1 \\
\hline $\begin{array}{l}\text { Liquid } \\
\text { yield, } \% \\
\text { wt. }\end{array}$ & 30,93 & $34.39^{\circ}$ & 34.91 & 32.33 & $32.46^{-}$ & $33.10^{-}$ & 34.5 & 35.11 & 33.52 & 33.93 \\
\hline$\rho, \mathrm{g} / \mathrm{cm}^{3}$ & 0.833 & 0.846 & 0.843 & 0.839 & 0.827 & 0.829 & $0.836^{-}$ & 0.825 & 0.837 & 0.847 \\
\hline RON & 105 & 107 & $102^{-}$ & $108^{--}$ & $109^{-}$ & $103^{-}$ & $103^{-}$ & $104^{--}$ & 105 & $103^{-\cdots}$ \\
\hline \multicolumn{11}{|c|}{ Ni-HZSM-5 } \\
\hline & $\mathrm{T1}$ & $\mathrm{T} 2$ & T3 & T4 & T5 & T6 & T7 & T8 & T9 & T10 \\
\hline $\begin{array}{l}\text { Temp. } \\
{ }^{\circ} \mathrm{C}\end{array}$ & 450 & $450^{-}$ & 450 & $450^{-}$ & $450^{-}$ & $450^{\circ}$ & $450^{-}$ & $450^{\circ}$ & $450^{-}$ & $450^{-}$ \\
\hline $\begin{array}{l}\text { Press., } \\
\text { atm. }\end{array}$ & 4 & $4^{-}$ & 4 & 4 & 4 & 4 & 4 & 4 & & 4 \\
\hline $\begin{array}{l}\text { WHSV, } \\
\mathrm{h}^{-1}\end{array}$ & 1 & 1 & 1 & 1 & 1 & 1 & 1 & 1 & 1 & $1^{-}$ \\
\hline $\begin{array}{l}\text { Liquid } \\
\text { yield, } \% \\
\text { wt. }\end{array}$ & 23.93 & 25.28 & 24.21 & 22.83 & 25,15 & 24,18 & 20,5 & $21.11^{-}$ & 24,32 & 23.97 \\
\hline $\mathrm{\rho}, \mathrm{g} / \mathrm{cm}^{3}$ & 0.777 & 0.769 & $0.743^{-}$ & 0.779 & 0.781 & 0.779 & 0.766 & $0.759^{-}$ & 0.7367 & $0.770^{\circ}$ \\
\hline $\mathrm{RON}^{-}$ & 99 & 98 & 100 & 99 & $100^{--}$ & 98 & $99^{-}$ & $99^{\circ}$ & $99^{-}$ & $98^{-}$ \\
\hline
\end{tabular}

Table 2

THE RON AND LIQUID PRODUCTS DENSITY RESULTS ON Zn-HZSM.5 CATALYST

Table 3

THE RON AND LIQUID PRODUCTS DENSITY RESULTS ON Ni-HZSM.5 CATALYST 
these materials (HZSM-5, Ni-HZSM-5, Zn-HZSM-5) and catalytic sites provided by these cations remove the kinetic bottlenecks that limit the rate and selectivity of alkanes aromatization reactions [82]. Ni-HZSM-5 exhibits lower alkanes conversion rates and aromatics formation rates than $\mathrm{Zn}-\mathrm{HZSM}-5$, because $\mathrm{Zn}^{2+}$ cations catalyze recombinative desorption steps more effectively than $\mathrm{Ni}^{2+}$ cations $[6,49,52,53,58-62,66]$.

The average output of the RON (Research Octane Number) and liquid products density of liquid fractions results on Zn-HZSM-5 and Ni-HZSM-5 catalysts in conversion of the butanes /butylenes, $\mathrm{C}_{4} / \mathrm{C}_{4}=$ technical fraction are presented in table 2 and 3.

The liquid fraction resulted on Zn-HZSM-5 and Ni-HZSM5 catalysts can be used as a blending mixture for the octane number enhancing of gasoline because the RON is over 98, or as raw materials for the production of petrochemicals and chemical intermediates, especially of the liquid fraction obtained over the Zn-HZSM-5 catalyst.

\section{Conclusions}

Bifunctional catalysts, Zn-HZSM-5 and Ni-HZSM-5, exhibit high selectivity to aromatics BTX (especially ZnHZSM-5) in the aromatization process of butanes-butenes mixture, due to dehydrogenation of alkanes to alkenes and dehydrocyclization of alkenic oligomers to naphthenic intermediates on exchanged $\mathrm{Zn}^{2+}$ and $\mathrm{Ni}^{2+}$ cations (Lewis strong acid sites), and of alkenes interconversion and aromatic formation on acid $\mathrm{OH}$ groups (Bronsted strong acid sites). The average output of aromatics BTX in the liquid phase represent more than $55 \mathrm{wt} . \%$ during the first 32 hours' time on stream on Ni-HZSM-5, and more than 75 wt.\% during the same time interval on stream on Zn-HZSM5. The significant production of aromatics is explained by the enhanced production of alkenes by the effective dehydrogenating action of zinc and nickel on alkanes and naphtenes intermediates.

The product distribution (gaseous and liquid) in the conversion of butanes-butenes mixtures at $450^{\circ} \mathrm{C}$ over $\mathrm{Zn}$ HZSM-5 and Ni-HZSM-5 catalysts is changing with time on-stream. The Zn-HZSM-5 catalyst are able to sustain activity and selectivity for a longer period.

The presence of butenes in the butanes feed exercises the activation of butanes: it is thought that butenes are the result of the protonation to carbenium ions from a Bronsted acid site and then activate butanes through hydride abstraction.

The catalytic activity of HZSM-5 catalyst in the aromatization process of butenes / butenes technical fraction can greatly be improved by the introduction of $\mathrm{Zn}^{2+}$ and or $\mathrm{Ni}^{2+}$ cations by ion exchange.

Zinc and nickel species affect the Brönsted acidity of the zeolite; the supplementary Lewis sites associated with the extra-framew ork of zinc and /or nickel species are provided, sites that are able to subtract hydride from the adsorbed hydrocarbons molecules and catalyze the formation of hydrogen gas.

The role of $Z n$ is mostfavorably attributed to the removal of hydrogen atoms from the zeolite surface through a reverse hydrogen spillover effect where $\mathrm{Zn}$ acts as active site for the recombination of hydrogen atoms to hydrogen molecules, in order to be desorbed to gas phase.

The acidic sites of zeolite would catalyze the oligomerization of light alkanes and the cyclization of $\mathrm{C}_{6}$ $\mathrm{C}_{8}$ alkenes or dienes.

In the presence of $\mathrm{Zn}^{2+}$ and $\mathrm{Ni}^{2+}$ cations, the aromatization of butanes /butenes technical mixture is changed from the cracking and the subsequent aromatization mechanism to the direct aromatization by dehydrogenation pathway.

The loss of catalytic activity of Zn-HZSM- 5 and Ni-HZSM5 catalysts with the reaction progress is a result of decreasing for the number of active sites upon coke deposition.

The catalytic aromatization reactions over Zn-HZSM-5 catalysts can upgrade the low-value light hydrocarbon byproduct streams from refinery and cracker operations, producing aromatics BTX and hydrogen as co-product.

Small selectivity for BTX aromatics of Ni-HZSM-5 (compare with Zn-HZSM-5 catalyst in conversion of butanes-butenes technical mixtures is very probably because $\mathrm{Zn}^{2+}$ cations catalyze recombinative desorption steps more effectively than $\mathrm{Ni}^{2+}$ cations

Zinc and Ni species working synergistically with the Brönsted and Lewis acid sites of the zeolite are responsible for the dehydrogenation of alkanes $\left(C_{3}(n+i) C_{4}\right)$ to alkenes $\mathrm{C}_{2}=-\mathrm{C}_{4}=$, alkenes oligomers $\mathrm{C}_{4}=-\mathrm{C}_{10}=$ to dienes $\mathrm{C}_{4}==-\mathrm{C}_{10}==$ and of cyclonaphtenes $C_{6}-C_{10}$ to aromatics $C_{6}-C_{10}$ and Bronsted and Lewis acid sites are responsible for the isomerisation of $\mathrm{n}-\mathrm{C}_{A}=$ to $\mathrm{i}-\mathrm{C}_{4}=$, oligomerization of $\mathrm{C}_{2}=-\mathrm{C}_{4}=$ to $C_{4}=-C_{10}=$ and cyclization of dienes $C_{4}==-C_{10}==$ to $^{2}$ cyclic naphtenes $\mathrm{C}_{6}-\mathrm{C}_{10}$.

\section{References}

1.YIN, C., WANG, J., DENG, W., LIU, C., Prepr. Pap.-Am. Chem. Sos. Div. Fuel Chem., 48,No.2, 2003, p.715.

2.NICOLAIDES, C. P., SINCADU, N. P. SCURREL, M. S., Catal. Today, 71, 2001, p.429.

3.BISCARDI, J. A., IGLESIA, E., J. Catal., 182, 1999, p. 117.

4.SEDDON, D., Catal. Today, 6, No.3, 1990, p.351.

5.ONO, Y., Catal. Rev.-Sci. Eng., 34,No.3, 1992, p.179.

6.GUISNET, M., GNEP, N. S., ALARIO, F., Appl. Catal. A, 89,1992, p.1.

7.TAYLOR, R. J., PETTY, R. H., Appl. Catal., 119, 1994, p.121.

8.MERIAUDEAU, P., NACCACHE, C., Catal. Rev. Sci. Eng., 39, No. 1-2, 1997, p. 5.

9.INUI, T., MAKINO, Y., OKAZUMI, F., MIYAMOTO, A., Stud. Surf. Sci. Catal., 37, 1987, p. 487.

10.BERNDT, H., LIETZ, G., LÜCKE, B., VOLTER, R., Appl. Catal. A: General, 146, No. 2, 1996, p. 351

11.BISCARDI, J.A., MEITZNER, G.D., IGLESIA, E., J. Catal., 179, no. 1, 1998, p. 192.

12.GIANETTO, G., MONQUE, G., R., PEREZ, J.A., PAPA, J., GARCIA, L., Zeolites, 13, 1993, p.557.

13.GIANETTO, G., PÉREZ, J.A., SCIAMANNA, R., GARCIA, L., GALIASSO, R., MONQUE, R., in DEROUANE, E.G., LEWIS, F., NACCACHE, A., RAMOA RIBEIRO, F., Eds., Zeolite Microporous Solids: Synthesis, Structure and Reactivity, NATO ASI C 352, 1992, Kluwer, Dordrecht.

14.WEITKAMP, J., RAICHLE, A., TRAA, Y., Appl. Catal. A: General, 222, 2001, p.277.

15.TANABE, K., HOLDERICH, W.F., Appl. Catal. A: General, 181, 1999, p. 399.

16.YU, H., WANG, X.-Q., LONG, Y.-C., Micropor. Mesopor. Mater., 95, No.1-3, 2006, p. 234.

17.SUBBOTINA, I.R., KAZANSKY, V.B., Petrol. Chem., 49, No.1, 2009, p. 11.

18.BHAN, A., DELGASS, W.N., Catal. Rev.-Sci. Eng., 50, No.1, 2008, p. 19.

19.CAEIRO, G., CARVALHO, R.H., WANG, X., LEMOS, M.A.N.D.A., LEMOS, F., GUISNET, M., RIBEIRO, F.R., J. Mol. Catal. A: Chem., 255, No.1-2, 2006, p. 131.

20.NGUYEN, L.H., VAZHNOVA, T., KOLACZKOWSKI, S.T., LUKYANOV, D.B., Chem. Eng. Ser., 61, 2006, p. 5881.

21.LUBANGO, L.M., SCURRELL, M.S., Appl. Catal. A: General, 235, No.1-2, 2002, p. 205.

22.MONTES, A., GIANNETTO, G., Appl. Catal. A: General, 197, 2000, p. 31. 
23.BISCARDI, J .A., IGLESIA, E., Catal. Today, 31, 1996, p. 207.

24.GUISNET, M., GNEP, N.S., Appl. Catal. A: General, 146, No.1, 1996, p. 33.

25.EL-MALKI, EI-M., VAN SANTEN, R.A., SACHTLER, W.M.H., J. Phys. Chem. B, 103, No.22, 1999, p. 4611.

26.MOWRY, J.R., MARTINDALE, D.C., HALL, H.P., Arab. J. Sci. Eng., 10, no.7, 1985, p. 367.

27.DOOLAN, P.C., PUJADO, P.R., Hydroc. Process, 68, No. 9, 1989, p. 726.

28.MANK, L., MINKKINEN, A., SHADICH, R., in: Hydrocarbon Technology, Harrison, P., Ed. Sterling Publication, London, 1992, p. 6985.

29.J OSHI, Y.V., THOMSON, K.T., Catal. Today, 105, 2005, p. 106.

30.J OSHI, Y.V., THOMSON, K.T., J. Catal., 246, No.2, 2007, p. 249.

31.HART, V.I., BRYANT, M.B., BUTLER, L.G., WU, X., DOOLEY, K.M., Catal. Lett., 53, 1998, p. 111.

32.ROMERO, F.J., ROLDAN, R., JIMENEZ, C., BORAU, V., MARINAS, J.M., Appl. Catal. A: General, 266, 2004, p. 203.

33.BHAN, A., DELGASS, W.N., Catal. Rev. Sci. Eng., 50, No. 1, 2008, p. 19.

34.CAEIRO, G. CARVALHO, R.H., WANG, X., LEMOS, M.A.N.D.A., LEMOS, F., GUISNET, M., RIBEIRO, F.R., J. Molec. Catal. A: Chemical, 255, No.1-2, 2006, p. 131.

35.FRICKE, R., KOSSLICK, H., LISCHKE, G., RICHTER, M., Chem. Rev., 100, No.6, 2000, p. 2303.

36.MERIAUDEAU, P., NACCACHE, C., Catal. Rev. Sci. Eng., 39, No. 1-2, 1997, p. 5.

37.ASAFTEI, I. V., EARAR, K., LUNGU, N. C., BIRSA, L., M., IGNAT, MARIA, PLESU, V., SANDU, I.G.,Rev. Chim. (Bucharest), 67, no.7, 2016, p. 734.

38.INUI, T., MAKINO, Y., OKAZUMI, F., MIYAMOTO, A., Stud. Surf. Sci. Catal., 37, 1987, p. 487.

39.INUI, T., MAKINO, Y., OKAZUMI, NAGANO, S., MIYAMOTO, A., Ind. Eng. Chem. Res., 26, No. 4, 1987, p.647.

40.IGLESIA, E., BAUMGARTNER, J.E., Catal. Lett., 21, 1993, p. 55.

41.DOOLEY, K.M., PRICE, G.L., KANAZIREV, V.I., HART, V.I., Catal. Today, 31, No. 3-4, 1996, p. 305.

42.MERIAUDEAU, P., NACCACHE, C., Catal. Today, 31, No. 3-4, 1996, p. 265.

43.PARK, Y.K., KIM, D.H., WOO, S.I., Korean J. Chem. Eng., 14, No. 4, 1997, p. 249.

44.ASAFTEI,I.V., LUNGU, N.C., SANDU, I., IGANT, M., Rev.Chim. (Bucharest). 68, no.4, 2017 p.715.

45.VISWANADHAM, N., MURALIDHAR, G., PRASADA RAO, T.S.R., J. Molec. Catal. A: Chemical, 223, No. 1-2, 2004, p. 269.

46.LUKYANOV, D.B., VAZHNOVA, T., Appl. Catal. A: General, 316, No. 1, 2007, p. 61.

47.SUBBOTINA, I.R., KAZANSKY, V.B., Petroleum Chemistry, 49, No. 1, 2009, p. 11.

48.BILBA, N., ASAFTEI, I., IOFCEA, GH., NAUM, N., in "Proceedings of the $12^{\text {th }}$ Int. Zeolite Conf".; TREACY M..M... ., MARCUS B.K., BISHER M.E., HIGGINS J .B., Eds.; Materials Research Society, Baltimore, USA, 1998, p. 2759.

49. ASAFTEI, I.V., EARAR, K., BIRSA, L.M.., SANDU, I.G., LUNGU, N.C.L., SANDU, I., REV.CHIM. (Bucharest), 66, no.7, 2015, p. 963.

50. ONO, Y., NAKATANI, H., KITAGAWA, H., SUZUKI, E., Stud. Surf. Sci. Catal., 44, 1989, p. 279.

51.ASAFTEI, I.V., LUNGU, N.C., BIRSA, L.M., SANDU,I.G., SARBU, L.G., IGANT, M., Rev.Chim. (Bucharest), 68. no.1, 2017 p.116.

52.ASAFTEI, I. V., BILBA, N., SANDU, I., Rev. Chim. (Bucharest), 65, no.6, 2014, p. 697.

53.ASAFTEI, I. V., BILBA, N., SANDU, I., Rev. Chim. (Bucharest), 64, no.8, 2013, p.838.

54.ASAFTEI, I.V., SANDU, I., LUNGU, N.C., SPAC, A.F., IGNAT, M.,ReV. Chim. (Bucharest), 69, no.4, 2018, p.938.
55.HAGEN A., ROESSNER, F., Stud. Surf. Sci. Catal.,98, 1995, p. 182. 56. FU, Z., YIN, D., YANG, Y., GUO, X., Appl. Catal. A: General, 124, No. 1, 1995, p. 59.

57.YANG, Y., GUO, X., DENG, M., WANG, L., FU, Z., Stud. Surf. Sci. Catal.,46, 1989, p. 849.

58.ASAFTEI, I.V., SANDU, I.G., BIRSA, L.M., MANEA, LILIANA, ROZEMARIE, EARAR, K., REV.CHIM. (Bucharest), 66, no.3, 2015, p.336.

59.BILBA, N., ASAFTEI, I., IOFCEA, GH, PADURARIU, D. M., PAVEL, C. C., Proceedings of the $13^{\text {th }}$ International Zeolite Conference, Montpellier, France, 8-13 J uly, 2001, 24-P-30, GALARNEAU, A., Di RENZO, F., FAJULA, F., VEDRINE, J., (Eds.), Studies in Surface Science and Catalysis, 135, 2001. p. 2791.

60.MAFTEI, D., ASAFTEI, I. V., SANDU, I., MANEA, LILIANA, ROZEMARIE, BIRSA, L.M., EARAR, K., Rev. Chim. (Bucharest), 66, no. 5, 2015, p.673. 61.ASAFTEI, I. V., BILBA, N., SANDU, I., Rev. Chim. (Bucharest), 65, no.4, 2014, p.431.

62.YU, S.Y., BISCARDI, J .A., IGLESIA, E., J.. Phys.Chem. B, 106, No.37, 2002, p. 642.

63.LUBANGO, L.M., SCURRELL, M.S., Appl.Catal.A:General, 235, No.12, 2002, p.265.

64.ASAFTEI, V.I., BILBA, N., SANDU, I., Rev. Chim. (Bucharest), 64, no.5, 2013, p.509.

65.DUFRESNE, L.A., LE VAN MAO, R., Catal. Lett., 25, No. 3-4, 1994, p. 371.

66.LI, Y., LIU, S., XIE, S., XU, L., Appl. Catal. A: General, 360, 2009, p.8. 67.ONO Y., KANAE, K., J. Chem. Soc., Faraday Trans., 1991, 87, p. 669. 68.SCURRELL, M. S., Appl. Catal., 41, 1988, p.89.

69.0NO, Y., Catal. Rev. Sci. Eng., 1992, 34 No.3, p.179.

70.GNEP, N. S., DOYEMET, J.Y., GUISNET, M., J. Mol. Catal., 45, 1988, p.281.

71. GNEP, N. S., DOYEMET J. Y., SECO, A. M., RIBEIRO, F. R, GUISNET, M., Appl. Catal., 1987, 35, 93.

72. ONO, Y. OSAKO, K. KIM, G. J., INOUE, Y., in Zeolites and Related Microporous Materials, State of the Art, Proceedings of the $10^{\text {th }}$ International Zeolite Conference Garmisch- Partenkirchen, Germany, Stud. in Surf. Sci. and Catalysis, 1994,84, Elsevier Ed., p.1773.

73. ASAFTEI, I.V., LUNGU, N. C., SANDU, I. G., SPAC, A. F., IGNAT, M., Rev. Chim. (Bucharest), 69, no.9, 2018, p.2420.

74.CHANGLONG, YIN., CHENGUANG LIU, Petroleum Science and Technology,. 23, No.9\&10, 2005, p. 1153.

75.VISWANADHAM, N., SAXENA, S, K., KUMAR, M., Petroleum Science and Technology, 29, No. 4, 2011, p. 393.

76.YU TING-YUN, QIAN J IAN-HUA, Petroleum Science and Technology, 24, No. 9, 2006, p. 1001.

77.CHANGLONG YIN, RUIYU ZHAO, CHENGGUANG LIU, Fuel, 84, No.6, 2005, p. 705.

78.ZIN, C., ZHAO, R., ZHAO, H., XU, Y., LIU, C., Petroleum Science and Technology, 25, No. 4, 2007, p. 491.

79.ONO.Y., OSAKO, K., INOUE, Y., in Proceedings of the $10^{\text {th }}$ Intern. Zeolite Conf. Garmisch-Parten Kirchen, Germany, July, 17-22, 1994, (Elsevier Eds.), Amsterdam, Netherland, p. 1733.

80.YU, S. Y., YU, G. J., LI, W., IGLESIA, E., J. Phys. Chem. B, 106, 2002, p.4714.

81.KIM, G.-J., KIM, K.-H, KO, W.-S., ONO, Y., J. Of Korean Ind.\& Eng. Chemistri, 5, No.6., December, 1994, p. 957.

82.CHOUDHARY, V.R., MULLA, S.A.R., BANERJEE, S., Micropor. Mesopor. Mater., 57, 2003, p. 317.

83.CHU, P. USPatent, 4120910, 1978.

84.CHU, P. CHESTER, A.W., USPatent, 4392989, 1983.

85.BILBA, N., BILBA, D., VASILE, A., CRUCEANU, M., ABABI, V., Brevet RO 96844, 1988.

86.OLSON, D.H., KOKOTAILO, G.T., LAWTON, S.L., MEIER, W.M., J. Phys. Chem., 85, 1981, p. 2238.

Manuscript received: 17.01 .2019 